\title{
Pengaruh BDNF dan Neurotrophin Receptor pada Derajat Hidrosefalus Kongenital Pasca Ventrikulo Peritoneal Shunt
}

\section{The Effect of BDNF and Neurotrophin Receptor in Congenital Hidrocephalus Severity after Ventriculo Peritoneal Shunt}

\author{
Farhad Bal'afif', $M$ Aris Widodo ${ }^{2}, M$ Istiadjid ES ${ }^{1}$, Abdul Hafid $B^{3}$ \\ ${ }^{1}$ Laboratorium Bedah Saraf Fakultas Kedokteran Universitas Brawijaya Malang \\ ${ }^{2}$ Laboratorium Farmakologi Fakultas Kedokteran Universitas Brawijaya Malang \\ ${ }^{3}$ Laboratorium Bedah Saraf Fakultas Kedokteran Universitas Airlangga Surabaya
}

\begin{abstract}
ABSTRAK
Peningkatan tekanan intrakranial (TIK) akibat hidrosefalus dapat menyebabkan penipisan cerebral mantle dan bertanggungjawab terhadap peningkatan Evan's ratio (ER). Apoptosis dan degenerasi neuron berperan penting pada perubahan patologis tersebut. Pada hidrosefalus berat terjadi ketidakpastian dari perbaikan pasca Ventrikulo-Peritoneal Shunt (V-P Shunt), yang diduga dipengaruhi oleh kadar Brain Derived Neurotropic Factor (BDNF) dan reseptornya. Penelitian ini bertujuan untuk membuktikan pengaruh Kadar BDNF, solubleTyrosine Kinase B (sTrkB) dan soluble P75 neurotrophin receptor $\left(\mathrm{sP} 75^{\mathrm{NTR}}\right)$ cairan serebrospinal terhadap perbaikan Evan's ratio hidrosefalus kongenital Pasca V-P Shunt. Cairan serebrospinal (CSS) diambil dari 22 sampel bayi hidrosefalus saat dilakukan V-P Shunt, 12 jam, 24 jam dan 3 bulan kemudian. Kadar BDNF, sTrkB dansP75 ${ }^{\text {NTR }}$ diukur menggunakan tehnik ELISA. Derajat hidrosefalus di ukur menggunakan Evan's ratio dari hasil CT-Scan sebelum dan 3 bulan pasca V-P Shunt. Hasil analisis data menunjukkan bahwa delta Evan's ratio 3 bulan pasca V-P Shunt pada hidrosefalus kongenital berkorelasi positif dengan kadar BDNF pre operatif dan berkorelasi negatif dengan kadar sTrkB pre operatif. Disamping itu delta Evan's ratio 3 bulan pasca V-P Shunt dipengaruhi secara negatif oleh delta BDNF dan sP75 ${ }^{\mathrm{NTR}}$ dan secara positif oleh delta sTrkB 3 bulan pasca V-P Shunt. Kadar BDNF, sTrkB dan SP75 ${ }^{N T R}$ terlibat pada respon adaptif otak karena peningkatan TIK akibat hidrosefalus kongenital dan berpengaruh pada perbaikan Evan's ratio pasca V-P Shunt.
\end{abstract}

Kata Kunci: BDNF, hidrosefalus kongenital, $\mathrm{P} 75^{\mathrm{NTR}}$, TrkB

\begin{abstract}
Elevated Intracranial pressure (ICP) due to hydrocephalus (HCP) causes some thinning in cerebral mantle and increasing of Evan's ratio (ER). Apoptosis and neuronal degeneration play an important role in this pathological change. The Evan's ratio improvement after Ventrikulo-Peritoneal Shunt (V-P Shunt) insertion in congenital hydrocephalus is uncertain, Brain Derived Neurotropic Factor (BDNF) and their receptors are predicted responsible factors. This research aimed to reveal the influence of BDNF, solubleTyrosine Kinase B (sTrkB) and soluble P75 neurotrophin receptor (sP75 $5^{N T R}$ ) level on Cerebrospinal fluid (CSF) toward Evan's ratio of congenital hydrocephalus post V-P Shunt. Cerebrospinal fluid (CSF) collected from 22 infants with hydrocephalus during V-P Shunt insertion, and 12 hours, 24 hours 3 months after surgery. The BDNF, sTrKB and $s P 75^{N T R}$ were measured and analyzed using ELISA technique. Grading HCP is performed using Evan's ratio from head CT before and 3 months after surgery. Data analysis showed that delta of Evan's ratio in congenital HCP patient correlated positively with preoperative level of BDNF and correlated negatively with preoperative level of sTrkB. The delta Evan's ratio 3 month after V-P Shunt is influenced negatively by delta of BDNF and sP7 $5^{N T R}$ and positively by delta of sTrkB 3 month following V-P Shunt. The preoperative level of BDNF and STrKB may represent an adaptive response of the brain due to elevated ICP in hydrocephalic patient. Their levels are correlated with HCP severity. The elevated post operative level of $B D N F$, STrKB and $s P 75^{N T R}$ contribute to Evan's ratio improvement.
\end{abstract}

Keywords: BDNF, congenital hydrocephalus, $P 75^{N T R}, \operatorname{TrKB}$

Jurnal Kedokteran Brawijaya, Vol. 27, No. 3, Februari 2013; Korespondensi: Farhad Bal'afif. Laboratorium Bedah Saraf Fakultas Kedokteran Universitas Brawijaya Malang, Jl. Jaksa Agung Suprapto No.2 Malang, Tel. (0341)333100 Email:farblf@rocketmail.com 


\section{PENDAHULUAN}

Hidrosefalus adalah suatu distensi aktif dari sistem ventrikel otak akibat sirkulasi cairan serebrospinal (CSS) yang tidak adekuat $(1,2)$. Secara patologis hidrosefalus akan menimbulkan glial scar, degenerasi akson, demyelinasi, gangguan pertumbuhan akson dan kematian sel terutama apoptosis (1,3-7). Perubahan sekunder terjadi pada sel bodi neuronal dan sinaps (6). Prevalensi tinggi pada bayi dan anak $(8,9)$.

Apoptosis dan degenerasi akson berperan pada penipisan Cerebral Mantle (CM) dan defisit neurologis pada hidrosefalus $(5,6)$. V-P Shunt akan menurunkan tekanan intrakaranial (TIK) dan distensi ventrikel, sehingga akan memperbaiki hidrosefalus $(1,10)$. Pada hidrosefalus berat, reekspansi kortek masih dimungkinkan (11), tetapi CM kurang dari $1 \mathrm{~cm}$ merupakan point of no return (12). Kedua pernyataan tersebut masih diperdebatkan. Dimungkinkan ada faktor biomolekuler yang ikut berperan.

Brain Derived Neurotrophic Factor (BDNF) merupakan neurotrophin yang berperan pada survival neuron, pertumbuhan akson, proliferasi, diferensiasi, myelinasi, perbaikan degenerasi, regenerasi dan neuroplastisitas neuron (13-16). BDNF berperan paradox tergantung reseptor yang teraktivasi, TrKB atau $P 75^{\text {NTR }}(17,18)$. Tampaknya kadar BDNF dan reseptor tersebut berperan dalam menentukan cedera sel otak dan berpengaruh pada gradasi atau prognosis hidrosefalus pasca V-P Shunt.

Di bidang klinik diperlukan adanya biomarker yang dapat meramalkan prognosis hidrosefalus kongenital pasca V-P Shunt dan diperlukan adanya terapi modulasi yang dapat mengoptimalkan hasil V-P Shunt. Sampai saat ini pemahaman tentang patofisiologi molekuler perbaikan hidrosefalus belum banyak diketahui. Hidrosefalus kongenital masih sangat terbatas, penelitian tentang neurotrophin pada umumnya juga sangat jarang, sehingga mendorong untuk dilakukan penelitian ini. Penelitian ini bertujuan untuk membuktikan pengaruh kadar BDNF, sTrKB, sP75 ${ }^{\text {NTR }}$ sebelum dan sesudah V-P Shunt terhadap Evan's ratio pada penderita hidosefalus kongenital.

\section{METODE}

Penelitian ini merupakan studi observasional analitik prospektif (19) dengan besar sampel sebanyak 22 kasus. Penelitian dilakukan di instalasi Bedah Sentral RSU Dr. Saiful Anwar Malang, laboratorium Biomedik Fakultas Kedokteran Universitas Brawijaya dan Laboratorium Prodia Malang, mulai Juli 2011 sampai dengan Maret 2012.

Subjek penelitian ini adalah penderita hidrosefalus kongenital yang memenuhi kriteria inklusi dan eksklusi. Kriteria inklusi adalah hidrosefalus kongenital derajat sedang dan berat menurut kriteria Evan's ratio (ER), dengan usia kurang dari 1 tahun. Kriteria eksklusi adalah adanya infeksi intrakranial aktif dan kelainan intrakranial lain yang memerlukan tindakan atau menyulitkan pengukuran ER.

Pada penelitian ini kadar BDNF, solubleTyrosine Kinase B (sTrkB) dan soluble P75 Neurotrophin Receptor (sP75 ${ }^{\mathrm{NTR}}$ ) cairan Serebrospinal diukur memakai metode ELISA (BDNF merek Emax Immunoassay System dengan nomer katalog G7610, TrkB merek ABGENT Immunoassay System dengan no katalog AP7687a dan p75 ${ }^{\mathrm{NGF}}$ merek Abcam
Immunoassay dengan no katalog ab61425). Sampel CSS diambil dari ventrikel pada saat operasi pemasangan V-P Shunt dan 3 bulan kemudian masing-masing $3 c c$. Untuk pengambilan sampel 12 jam dan 24 jam pasca V-P Shunt hanya dapat dilakukan pada 11 pasien. Sampel CSS dibagi menjadi 3 tabung canovial screw cup yang masing-masing untuk mengukur kadar BDNF, sTrkB dan SP75 ${ }^{\mathrm{NTR}}$. Dari 22 pasien tersebut juga diukur Evan's ratio (ER) sebelum dan 3 bulan pasca V-P Shunt dengan menggunakan CT-Scan kepala. Besar ER diukur berdasarkan CT-Scan kepala sebelum dan 3 bulan setelah V-P Shunt. Penelitian ini menggunakan uji statistik Structural Equation Modeling (SEM) dan T- Test.

\section{HASIL}

Didapatkan 29 pasien hidrosefalus kongenital yang memenuhi kriteria inklusi dan eksklusi, tetapi 7 pasien dikeluarkan dari penelitian (drop out), disebabkan karena infeksi (2 pasien), meninggal (4 pasien) dan menolak untuk diteruskan (1 pasien). Dari sisa 22 pasien didaparkan usia termuda 8 hari dan yang paling tua 12 bulan pada saat operasi V-P Shunt dilakukan, usia terbanyak 0-6 bulan sebesar $72 \%$ dan $6-12$ bulan sebesar $28 \%$.

Hasil rerata ER pre op 0,67 dan rerata ER 3 bulan pasca V-P Shunt 0,60 , uji $t$ tes menunjukkan penurunan ER pasca $V-P$ Shunt yang sangat bermakna $(p=0,001)$. Hasil uji SEM, pengaruh BDNF, sTrKB dan $\mathrm{SP} 75^{\mathrm{NTR}}$ pre op terhadap $\triangle \mathrm{ER} 3$ bulan pasca V-P Shunt dapat dilihat pada Tabel 1.

Dari hasil tersebut terlihat bahwa tingginya kadar BDNF sebelum V-P Shunt berpengaruh buruk pada perbaikan derajat hidrosefalus, sedangkan kadar sTrkB berpengaruh baik dan SP75 ${ }^{\text {NTR }}$ tidak berpengaruh pada perbaikan, akan tetapi ada kecenderungan berpengaruh buruk dengan besar pengaruh hanya 0,17\% sehingga secara statistik tidak bermakna. Karena efek antagonis dari sTrkB dan SP75 ${ }^{\text {NTR }}$ terhadap TrkB dan P75 ${ }^{\mathrm{NTR}}$, maka hal ini bermakna bahwa BDNF dan TrkB sebelum V-P Shunt berpengaruh buruk pada perbaikan hidrosefalus, sedangkan $\mathrm{P} 75^{\mathrm{NTR}}$ walaupun statistik tidak bermakna akan tetapi ada kecenderungan berpengaruh baik pada perbaikan.

Tabel 1. Hasil analisis BDNF,sTrKB dan sP75NTR pre op terhadap $\triangle$ ER 3 bulan pasca V-P Shunt

\begin{tabular}{|c|c|c|c|}
\hline \multirow{2}{*}{ Pengaruh antar Variabel } & \multicolumn{2}{|r|}{ Koefisien } & \multirow{2}{*}{ p Value } \\
\hline & Jalur & Determinasi & \\
\hline $\begin{array}{l}\text { BDNF pre op } \rightarrow \Delta \text { ER 3bulan-pasca } \\
\text { V-P Shunt }\end{array}$ & 0,444 & 0,395 & 0,001 \\
\hline $\begin{array}{l}\text { sTrKB pre op } \rightarrow \Delta \text { ER 3bulan- pasca } \\
\text { V-P Shunt }\end{array}$ & $-0,411$ & 0,395 & 0,015 \\
\hline $\begin{array}{l}\text { sP75NTR pre op } \rightarrow \Delta E R \text { 3bulan- } \\
\text { pasca V-P Shunt }\end{array}$ & 0,170 & 0,395 & 0,317 \\
\hline
\end{tabular}

Keterangan: Tampak BDNF pre op berkorelasi positif terhadap $\Delta$ ER dan sTrKB pre op berkorelasi negatif terhadap $\triangle E R$, sedangkan $S P 75^{\text {NTR }}$ berkorelasi positif tetapi tidak signifikan

Pre op = sebelum V-PShunt

Untuk hasil uji SEM pengaruh peningkatan kadar BDNF, STrKB dan SP75 ${ }^{\text {NTR }}$ secara serial 12 jam, 24 jam dan 3 bulan pasca V-P Shunt terhadap $\triangle$ ER 3 bulan-pasca V-P Shunt dapat dilihat pada Tabel 2, 3 dan 4. Dari tabel 2 dan 3 tampak penambahan derajat hidrosefalus ( $\triangle E R$ B bulan- 
pasca V-P Shunt) dipengaruhi secara negatif oleh peningkatan BDNF pasca V-P Shunt terutama 24 jam pertama $(P=0,001)$, dan secara positif oleh peningkatan kadar sTrkB pada 24 jam pertama $(P=0,001)$ dan secara negatif oleh peningkatan kadar SP75 ${ }^{\mathrm{NTR}}(\mathrm{P}=0,001)$.

Tabel 2. Hasil data analisis $\Delta$ BDNF secara serial terhadap $\Delta$ ER 3 bulan pasca V-P Shunt

\begin{tabular}{|c|c|c|c|}
\hline \multirow{2}{*}{ Pengaruh antar variabel } & \multicolumn{2}{|c|}{ Koefisien } & \multirow{2}{*}{ p Value } \\
\hline & Jalur & Determinasi & \\
\hline $\begin{array}{l}\Delta \text { BDNF 3bulan-pre op } \rightarrow \Delta E R \text { 3bulan- } \\
\text { pasca V-P Shunt }\end{array}$ & $-0,20$ & 0,949 & 0,005 \\
\hline $\begin{array}{l}\triangle \text { BDNF 24jam-pre op } \rightarrow \triangle E R \text { 3bulan- } \\
\text { pasca V-P Shunt }\end{array}$ & $-0,313$ & 0,949 & 0,001 \\
\hline $\begin{array}{l}\triangle B D N F \text { 12jam-pre op } \rightarrow \Delta E R \text { 3bulan- } \\
\text { pasca V-P Shunt }\end{array}$ & $-0,276$ & 0,949 & 0,001 \\
\hline $\begin{array}{l}\Delta s \text { P75 NTR 3bulan-pre op } \rightarrow \Delta E R \text { 3bulan- } \\
\text { pasca V-P Shunt }\end{array}$ & $-0,586$ & 0,949 & 0,001 \\
\hline $\begin{array}{l}\Delta s P 75^{N T R} 24 j a m \text {-pre op } \rightarrow \Delta E R \text { 3bulan } \\
\text { pasca V-P Shunt }\end{array}$ & $-0,351$ & 0,949 & 0,001 \\
\hline $\begin{array}{l}\Delta \text { sP75 NTR } 12 \text { jam-pre op } \rightarrow \Delta E R \text { 3bulan } \\
\text { pasca V-P Shunt }\end{array}$ & $-0,144$ & 0,949 & 0,044 \\
\hline
\end{tabular}

Keterangan: Tampak $\Delta \mathrm{sP} 75^{\mathrm{NTR}}$ secara serial berpengaruh negatif terhadap $\triangle E R$

Pre op = sebelum V-PShunt

Dari hasil analisis tersebut terlihat bahwa peningkatan kadar BDNF dan SP75 ${ }^{\text {NTR }}$ pasca V-P Shunt berpengaruh positif pada perbaikan hidrosefalus, dan kadar sTrkB pada 24 jam pertama berpengaruh negatif pada perbaikan hidrosefalus. Oleh karena efek antagonis dari sTrkB dan SP75 ${ }^{\text {NTR }}$ terhadap TrkB dan P75 ${ }^{\text {NTR }}$, maka secara keseluruhan dapat disimpulkan bahwa peningkatan kadar BDNF dan TrkB (24 jam pertama) berpengaruh baik pada perbaikan derajat hidrosefalus, sedangkan peningkatan kadar $\mathrm{P} 75^{\mathrm{NTR}}$ berpengaruh buruk pada perbaikan tersebut.

Tabel 3. Hasil data analisis $\Delta s \operatorname{TrKB}$ secara serial terhadap $\Delta E R$ 3 bulan pasca V-P Shunt

\begin{tabular}{|c|c|c|c|}
\hline \multirow{2}{*}{ Pengaruh antar variabel } & \multicolumn{2}{|r|}{ Koefisien } & \multirow{2}{*}{ p Value } \\
\hline & Jalur & Determinasi & \\
\hline $\begin{array}{l}\Delta \text { sTrkB 3bulan-pre op } \rightarrow \Delta \text { ER 3bulan- } \\
\text { pasca V-P Shunt }\end{array}$ & 0,023 & 0,949 & 0,752 \\
\hline $\begin{array}{l}\Delta \text { sTrkB 24jam-pre op } \rightarrow \Delta \text { ER 3bulan- } \\
\text { pasca V-P Shunt }\end{array}$ & 0,430 & 0,949 & 0,001 \\
\hline $\begin{array}{l}\Delta \text { sTrkB 12jam-pre op } \rightarrow \Delta \text { ER 3bulan- } \\
\text { pasca V-P Shunt }\end{array}$ & 0,251 & 0,949 & 0,001 \\
\hline
\end{tabular}

Keterangan: Tampak $\Delta$ sTrKB secara serial berpengaruh positif terhadap $\triangle$ ER walaupun pada 3 bulan pasca V-P Shunt tidak signifikan Pre op = sebelum V-PShunt

\section{DISKUSI}

Tindakan V-P Shunt berefek positif pada perbaikan hidrosefalus kongenital. Rekate et al melaporkan tindakan diversi CSS akan segera menurunkan TIK dan distensi ventrikel, sehingga cerebral mantle akan menebal (10). Hasil ini juga mendukung pendapat dari Greenberg bahwa pada hidrosefalus berat masih dapat terjadi reekspansi korteks pasca V-P Shunt. Hal ini tidak sesuai dengan pendapat Espay yang menyebutkan bahwa cerebral mantle kurang dari 1 sentimeter merupakan point of no return. Ventrikulomegali dipengaruhi oleh faktor lain selain TIK, antara lain penurunan turgor otak yang disebabkan oleh sekuele pasca infeksi, perdaran, radiasi dan cedera otak $(11,12)$.

Pemasangan V-P Shunt atau diversi CSS akan menyebabkan penurunan dilatasi ventrikel (penurunan ER) dan berhubungan dengan meningkatnya ketebalan cortical mantle, hal ini juga dihubungkan dengan perkembangan fungsi neuropsikologis $(19,20)$. Juga dilaporkan adanya korelasi terbalik antara ventricle brain ratio (VBR) dengan bayley mental scale. Hal ini menunjukkan adanya korelasi antara brain mass dengan IQ $(11,21,22)$. Dari hasil penelitian sebelumnya (tahap 1) diketahui bahwa tingginya kadar BDNF dan sTrkB serta penurunan $\mathrm{SP} 75^{\mathrm{NTR}}$ menggambarkan beratnya derajat hidrosefalus, sehingga berakibat negatif pada perbaikan. Dari fakta di atas tampak bahwa kadar BDNF dan sTrkB sebelum V-P Shunt lebih mencerminkan respon adaptif terhadap hidrosefalus (23), dan tampaknya dapat dijadikan marker untuk faktor prognostik terhadap keberhasilan V-P Shunt pada hidrosefalus kongenital. Ekspresi BDNF pada kondisi normal diproduksi dalam jumlah kecil, kemudian bila terjadi hipoksia dan iskemia akan terjadi aktivasi $\mathrm{Ca}^{2+}$ regulated pathway yang berakibat pada upregulasi BDNF, sehingga apoptosis menurun (2426). Ekspresi BDNF dan reseptornya berperan pada respon neuroprotektif endogen terhadap perubahan biomolekuler penderita hidrosefalus.

Hochhaus melaporkan adanya peningkatan kadar Nerve Growth Factor (NGF) dan Neutotrophin-3 (NT-3) pada CSS anak hidrosefalus dibandingkan dengan anak kejang demam (23). Shinoda et al melaporkan adanya peningkatan mRNA NGF, NT-3 dan TrkC pada struktur paraventrikuler hewan coba hidrosefalus, namun tidak ditemukan laporan kadar $\mathrm{P} 75^{\mathrm{NTR}}$ pada hidrosefalus (27).

Perubahan kadar BDNF, sTrkB dan SP75 ${ }^{\mathrm{NTR}}$ pasca V-P Shunt dapat menerangkan patofisiologi perbaikan hidrosefalus setelah pemasangn V-P Shunt. Tindakan V-P Shunt akan menyebabkan penurunan TIK dan distensi sistem ventrikel otak, sehingga akan menurunkan kaskade iskemia dan berkibat pada perbaikan klinis (4). V-P Shunt juga akan akan berpengaruh pada penurunan kadar IL-1 $\beta$ dan IL-6 (28). Pada penelitian ini respon adaptif otak pada hidrosefalus tampak masih terus terjadi pasca V-P Shunt. Hal ini mungkin karena neurotrophin diperlukan untuk fungsi neurorestorasi, antara lain untuk memperbaiki neurodegenerasi, karena pada hidrosefalus diketahui terjadi degenerasi neuronal (7). Neurotrophin juga dapat meningkatkan pertumbuhan akson, myelinasi, dan regenerasi neuron (16). Upregulasi BDNF pada cedera sel otak merupakan peran neuroprotektif dan neururestoratif dari neurotrophin tersebut (29). Pada otak mamalia sebagian besar neuron dihasilkan pada masa embrionik, dan pada otak matur jumlah neuron relatif konstan (30).

Saat ini diketahui bahwa sepanjang hidup mamalia tetap dapat menghasilkan neuron baru dari progenitas atau stem cell yang ada dalam zona subgranuler dari girus dentatus hipokampus dan zona subventrikuler dari ventrikel lateralis. Potensi proliferasi dari sel progenitor ini memberikan kapasitas pada otak matur untuk terjadinya plastisitas dan self-repair melalui neurogenesis sebagai respon dari stimuli eksternal dan cedera (iskemia dan trauma) (31). BDNF merupakan salah satu growth factor 
yang mempengaruhi neurogenesis tersebut. Sinaptogenesis (sprouting dari akson dan perubahan pada spines dari dendrit) merupakan mekanisme lain plastisitas dan self-repair setelah cedera iskemia pada otak (32). Plastisitas ini lebih aktif pada anak-anak dibandingkan dewasa, karena organisasi jaringan sinaptik neuronal dan jaras-jaras white matter masih dalam proses pembentukan menjadi dewasa (33).

Dari hasil penelitian ini terlihat peningkatan kadar BDNF dan STrKB 24 jam pertama dan penurunan $S P 75^{\text {NTR }}$ berpengaruh pada perbaikan hidrosefalus pasca V-P Shunt, sehingga obat-obat neuromodulator yang dapat meningkatkan kadar BDNF dan STrKB atau menurunkan $S P 75^{\mathrm{NTR}}$ dapat bermanfaat untuk terapi tambahan pada

\section{DAFTAR PUSTAKA}

1. Rekate HL. Definition and Classification of Hydrocephalus: A Personal Recommendation to Stimulate Debate. Cerebrospinal Fluid Research. 2008; 5: 2.

2. Iencean ST, Ciurea AV, and Poeata I. Intracranial Hypertension due to Disorders in the Cerebrospinal Fluid Dynamics-Review. Romanian Neurosurgery. 2009; 16(1): 18-21.

3. McCullough DC. Hydrocephalus: Etiology, Pathologic Effects, Diagnosis, and Natural History. In: Mc lourin $\mathrm{RL}(\mathrm{Ed})$. Pediatric Neurosurgery 2nd edition. Philadelphia: WB Sounders Company; 1989; p. 180199.

4. Ferderhoff-Mueser U, Herald R, Hochhause F, et al. Increased Cerebrospinal Fluid Concentrations of Soluble Fas (CD95/Apo-1) in Hydrocephalus. Archives of Disease in Childhood. 2001; 84 (4) : 369-372.

5. Ding $\mathrm{Y}, \mathrm{Yao} \mathrm{B}$, Lai Q, and McAllister JP. Impaired Motor Learning and Diffuse Axonal Damage in Motor and Visual Systems of the Rat Following Traumatic Brain Injury. Neurological Research. 2001; 23 (2-3): 193202.

6. Del Bigio MR and Enno TL. Effect of Hydrochepalus on Rat Brain Intracelluler Compartment. Cerebrospinal Fluid Research. 2008; 10(5): 12.

7. Schafer DP, Jha Smita, Liu F, et al. Destruction of the Axon Initial Segment Cytoskeleton is a New Mechanism for Neuronal Injury. The Journal of Neuroscience. 2009; 29(42): 13242-13254.

8. Zhang J, Williams MA, and Rigamonti D. Genetic of Human Hydrocephalus. Journal of Neurology. 2006; 253(10): 1255-1266.

9. Garne E, Loane M, Addor MC, Boyd PA, Barisic I, and Dolk H. Congenital Hydrocephalus-Prevalence, Prenatal Diagnosis and Outcome of Pregnancy in Four Euorupean Regions. European Journal of Paediatric Neurology. 2010; 14 (2): 150-155.

10. Rekate HL, Nadkarni TD, and Wallace D. The Importance of the Cortical Subarachnoid Space in Understanding Hydrocephalus. Journal of Neurosurgery Pediatrics. 2008; 2(1):1-11.

11. Greenberg MS. Hydrocephalus. In: Greenberg MS hidrosefalus pasca V-P Shunt. Dapat disimpulkan bahwa perbaikan hidrosefalus pasca V-P Shunt dipengaruhi secara positif oleh peningkatan kadar BDNF dan $\mathrm{SP} 75^{\mathrm{NTR}}$ dan oleh penurunan kadar sTrkB. Tingginya kadar BDNF dan rendahnya kadar sTrkB pre op menggambarkan beratnya hidrosefalus dan berbanding terbalik dengan perbaikan pasca V-P Shunt. Hal ini menggambarkan adanya respon adaptif otak pada peningkatan TIK akibat hidrosefalus. Disarankan perlu dilakukan pemeriksaan kadar BDNF dan sTrKB pre op sebagai bahan pertimbangan perlu tidaknya V-P Shunt dilakukan, khususnya pada kasus yang kontroversial. Disamping itu diperlukan pemberian terapi modulasi yang dapat memacu meningkatkan BDNF pada hidrosefalus pasca V-P Shunt.

(ed). Handbook of Neurosurgery. New York: Thieme; 2006; p. 180-207.

12. Espay AJ. Hydrocephalus. (Online) Sep. 2010. http//eMedicine.medscape.com/article/11235286. [diakses tanggal 28 September 2010].

13. Mattson MP. Neuroprotective Signal Transduction: Relevance to Stroke. Neuroscience and Biobehavioral Reviews. 1997; 21 (2): 193-206.

14. Semkova I and Krieglstein J. Neuroprotection Mediated Via Neurotrophic Factors and Indication of Neurotropic Factors. Brain Research Review. 1999; 30(2): 176-188.

15. Walton $\mathrm{M}$, Henderson $\mathrm{C}$, Parker $\mathrm{M}$, et al. Immediate Early Gene Transcription and Synaptic Modulation. Journal of Neuroscience Research. 1999; 58(1): 96106.

16. Saha RN, Liu X, and Pahan K. Up-regulation of BDNF in Astrocytes by TNF- $\alpha$ : A Case for the Neuroprotective Role of Cytokine. Journal of Neuroimmune Pharmacology. 2006; 1(3): 212-222.

17. Dechant G and Barde YA. The Neurotrophin Receptor p75 (NTR): Novel Functions and Implications for Diseases of the Nervous System. Nature Neuroscience. 2002; 5(11): 1131-1136.

18. Roux PP and Barker PA. Neurotrophin Signaling Through The $p 75$ Neurotrophin Receptor. Progress in Neurobiology. 2002; 67(3): 203-233.

19. Solimun. Bahan Ajar Metode Kuantitatif. Malang: Grahadi Media; 2007.

20. Venkaratama NK and Mukundan ER. Evaluation of Functional Outcomes in Congenital Hydrocephalus. Journal of Pediatric Neurosciences. 2011; 6(1): 4-12.

21. Young KM, Merson TD, Sotthibundhu A, Coulson EJ, and Bartlett PF. p75 Neurotrophin Receptor Expression Defines a Population of BDNF-Responsive Neurogenic Precursor Cells. The Journal of Neuroscience. 2007; 27(19): 5146-5155.

22. Ambarki $K$, Israelsson $H$, Wåhlin A, Birgander R, Eklund $A$, and Malm J. Brain Ventricular Size in Healthy Elderly: Comparison Between Evans Index and Volume Measurement. Neurosurgery. 2010; 67(1): 94-99.

23. Hochhaus F, Koehre P, Schaper C, et al. Elevated Nerve 
Growth Factor and Neurotrophin-3 Levels in Cerebrospinal Fluid of Children with Hydrocephalus. Biomentral Pediatrics. 2001; 1: 2.

24. Chau BN, Cheng EH, Kerr DA, and Hardwick JM. Aven, a Novel Inhibitor of Caspase Activation, Binds BCl-xL and Apaf-1. Molecular Cell. 2000; 6(1): 31-40.

25. Lu P, Jones LL, and Tuszynski MH. BDNF Expressing Marrow Stromal Cells Support Exfensive Axonal Growth at Sites of Spinal Card Injury. Experimental Neurology. 2004; 191(2):344-360.

26. Cadet JL and Krasnova IN. Cellular and Molecular Neurobiology of Brain Preconditioning. Molecular Neurobiology. 2009; 39(1): 50-61.

27. Shinoda $M$, Hidaka $M$, Lindqvist $E$, et al. NGT, NT-3 and TrkC mRNAs, but Not TrkA mRNA, are Upregulated in the Paraventricular Structure in Experimental Hydrocephalus. Childs Nervous System. 2001; 17 (12): 704-712.

28. Maliawan S, Asadul AI, and Mahadewa B. The Clinical Improvement Between Ventriculo-Peritoneal Shunt and Endoscopic Third Ventriculostomy. World Federation of Neuro-surgical Societies, 13th Interim Meeting/The 12th Asian-Australian Congress of
Neurological Surgeons. Nagoya-Japan, November 1822, 2007.

29. Juric DM, Loncar D, and Carman-Krzan M. Noradrenergic Stimulation of BDNF Synthesis in Astrocytes: Mediation Via a1-and B1/B2-Adrenergic Receptor. Neurochemistry International. 2008; 52(12): 297-306.

30. Kaslin J, Ganz J, and Brand M. Proliferation, Neurogenesis and Regeneration in the NonMammalian Vertebrate Brain. Philosophical Transactions of the Royal Society of London Series B Biological Sciences. 2008; 363(1489): 101-122.

31. Blurton-Jones W, Kitazawa M, Martinez-Coria $\mathrm{H}$, et al. Neural Stem Cell Improve Cognition via BDNF in a Transgen C Model of Alzheimer disease. Proceedings of the National Academy of Sciences of the United States of America. 2009; 106(32): 13594-13599.

32. Obrenovitch TP. Molecular Physiology of Preconditioning-Induced Brain Tolerance to Ischemia. Physiological Review. 2008; 88(1): 211-247.

33. Johnston MV, Ishida A, Ishida WN, et al. Plasticity and Injury in the Developing Brain. Brain and Development. 2009; 31(1): 1-10. 